\title{
Peroral xylitol increases the concentration levels of tissue iron
}

\section{in the rat}

\author{
BY MAURI M. HÄM ÄLÄINEN AND KAUKO K. MÄKINEN \\ Department of Biochemistry, Institute of Dentistry, University of Turku, \\ SF-20520 Turku 52, Finland
}

(Received 27 August 1982-Accepted 28 January 1983)

1. The effect of xylitol feeding on the iron content of rat tissues was studied.

2. Adult male rats were fed on the basal diet containing $(\mathrm{g} / \mathrm{kg}) 200$ glucose, or 50 or $200 \mathrm{xylitol}$, or the same diet containing no added carbohydrates for 8 weeks. Each feeding group comprised nine animals.

3. Xylitol at $200 \mathrm{~g} / \mathrm{kg}$ diet retarded the growth rate of the rats, whereas $200 \mathrm{~g}$ glucose $/ \mathrm{kg}$ increased the weight gains compared with animals given no added carbohydrates.

4. Xylitol at $50 \mathrm{~g} / \mathrm{kg}$ did not affect the tissue Fe concentrations, but $200 \mathrm{~g}$ xylitol $/ \mathrm{kg}$ increased the $\mathrm{Fe}$ content of the livers, duodenum wall, spleen, bone marrow and serum.

5. Cadmium and lead contents of the livers were similar in all groups.

6. Xylitol-Fe complexes are suggested to be responsible for the increased Fe absorption during xylitol feeding.

Administration of polyols together with iron may have beneficial effects on the absorption of $\mathrm{Fe}$ as shown with a polyol of the hexitol type, i.e. sorbitol (Herndon et al. 1958). The increased absorption may be associated with the known complex formation between polyhydroxy ligands and a metal cation (Angyal \& Davies, 1971; Angyal et al. 1974; Kieboom et al. 1975; Angyal \& Mills, 1979). Since experimental animals and humans tolerate xylitol better than sorbitol (Mäkinen, 1978), and since there has been no report on the effects of pentitol feeding on tissue Fe levels, we were prompted to study the effect of peroral xylitol on the tissue Fe levels in the rat.

\section{EXPERIMENTAL}

\section{Animals and experimental design}

The study was carried out with thirty-six inbred Long-Evans male rats aged 16 weeks. The rats (weight 300-360 g) were randomly divided into four groups of nine animals for an 8-week experiment involving peroral administration of xylitol or glucose. Before the study the rats were given unrefined stock diet which contained $200 \mathrm{mg}$ ferrous fumarate $/ \mathrm{kg}$ (Hämäläinen \& Mäkinen, 1981). Drinking-water (tap-water, $\mathrm{Fe}$ content $0.1 \mathrm{mg} / \mathrm{l}$ ) was available at all times. At the onset of the experimental feeding period, the normal pelleted food of the animals was replaced with a porridge-like food that consisted of water-ground stock diet mixture $(1: 1 \mathrm{w} / \mathrm{w})$. This food thus contained $100 \mathrm{mg}$ ferrous fumarate $/ \mathrm{kg}$. The daily consumption level of $\mathrm{Fe}$ was approximately $0.82 \mathrm{mg}$ per animal. Four different experimental foods were prepared from the basal diet for each of the four groups (Table 1). One group (control group) was given a diet that contained no added carbohydrates, the second group a $200 \mathrm{~g}$ glucose $/ \mathrm{kg}$ diet, the third group a $50 \mathrm{~g} \mathrm{xylitol} / \mathrm{kg}$ diet and the fourth group a $200 \mathrm{~g}$ xylitol $/ \mathrm{kg}$ diet. The 50 and $200 \mathrm{~g} / \mathrm{kg}$ levels of carbohydrates in the diets corresponded to $3.1 \mathrm{~g}$ and $12 \mathrm{~g}$ daily consumption of glucose or xylitol $/ \mathrm{kg}$ body-weight, respectively. No refusals and spills with the porridge-like food were observed; all food was consumed and the ingested amounts were similar in all rats. 
Table 1. The feeding regimen of rats receiving glucose or xylitol for 8 weeks (Nine animals in each experimental group. The xylitol in the $200 \mathrm{~g} x y l i t o l / \mathrm{kg}$ and $200 \mathrm{~g}$ glucose $/ \mathrm{kg}$ groups was increased progressively, the final $200 \mathrm{~g} / \mathrm{kg}$ level was maintained during the last 5 weeks of the regimen)

\begin{tabular}{|c|c|c|c|c|c|}
\hline \multirow[b]{2}{*}{$\begin{array}{l}\text { Period of experiment } \\
\text { (weeks) }\end{array}$} & \multirow[b]{2}{*}{ Dietary group } & \multicolumn{4}{|c|}{ Carbohydrate added to solid food $(\mathrm{g} / \mathrm{kg})$} \\
\hline & & Control & $\begin{array}{c}200 \mathrm{~g} \\
\text { Glucose } / \mathrm{kg}\end{array}$ & $\begin{array}{c}50 \mathrm{~g} \\
\text { Xylitol } / \mathrm{kg}\end{array}$ & $\begin{array}{c}200 \mathrm{~g} \\
\text { Xylitol } / \mathrm{kg}\end{array}$ \\
\hline 1 & & 0 & 5 & 5 & 5 \\
\hline 2 & & 0 & 10 & 5 & 10 \\
\hline 3 & & 0 & 15 & 5 & 15 \\
\hline $4-8$ & & 0 & 20 & 5 & 20 \\
\hline
\end{tabular}

\section{Collection of organs}

At the termination of the experimental feeding period, the rats were killed with an overdose of diethyl ether. Blood, the left lobe of the liver, the left kidney, spleen, a $30 \mathrm{~mm}$ section of the duodenum (immediately following the pyloric sphincter) and the femural bone marrow were collected. The bone marrow was freeze-dried, and the duodenum samples were carefully washed with cold water before chemical assays. Serum was separated from blood by centrifugation at $3500 \mathrm{~g}$ for $10 \mathrm{~min}$ at $4^{\circ}$.

\section{Chemical methods}

Tissue samples $(0 \cdot 1-0.5 \mathrm{~g})$ were digested by the wet-ashing method (Bothwell \& Finch, 1962). Serum proteins were precipitated with $200 \mathrm{~g}$ trichloroacetic acid $/ \mathrm{kg}$ containing $20 \mathrm{ml}$ thioglycolic acid/l. The protein-free filtrates of the sera and the digested tissue samples were analysed for $\mathrm{Fe}$ by the ferrozine method (Feldkamp et al. 1977). The cadmium and lead contents of the acid-digested liver samples were determined using a Perkin-Elmer 5000 atomic absorption spectrophotometer equipped with a graphite furnace HCA 500 (PerkinElmer Corporation, Norwalk, CT, USA).

\section{RESULTS}

The body-weight changes of the animals are shown in Table 2 . The body-weights increased in the $200 \mathrm{~g}$ glucose $/ \mathrm{kg}$ group and decreased in the $200 \mathrm{~g}$ xylitol $/ \mathrm{kg}$ group, the latter change being significant. Xylitol at $50 \mathrm{~g} / \mathrm{kg}$ diet had no significant effect on weight gains. All animals tolerated the ingested carbohydrates well. The death rate was zero and the stools of the rats given $200 \mathrm{~g}$ xylitol $/ \mathrm{kg}$ diet were normal.

The Fe contents of the organs are given in Table 3. Xylitol at $50 \mathrm{~g} / \mathrm{kg}$ diet increased the Fe content of the liver and spleen, but $200 \mathrm{~g}$ xylitol $/ \mathrm{kg}$ increased the Fe content in all organs except the kidneys. The most significant elevations in the Fe contents were found in the liver and bone marrow. Glucose at $200 \mathrm{~g} / \mathrm{kg}$ also increased the Fe content of the liver and spleen, but the general trend was that the Fe levels were highest in rats given $200 \mathrm{~g} \mathrm{xylitol} / \mathrm{kg}$ diet. The glucose-fed rats had significantly lower serum Fe levels than the other animals. Consequently, the transport of $\mathrm{Fe}$ in the blood differed significantly depending on whether the animals were given $200 \mathrm{~g}$ glucose $/ \mathrm{kg}$ or $200 \mathrm{~g}$ xylitol $/ \mathrm{kg}$ diet, indicating a different rate of translocation of $\mathrm{Fe}$ from blood to $\mathrm{Fe}$-concentrating tissues, or facilitated transport of $\mathrm{Fe}$ from the intestinal lumen to the blood during xylitol feeding.

The $\mathrm{Cd}$ and $\mathrm{Pb}$ analyses of the livers showed only insignificant amounts of these metals; the highest values determined were as follows: $\mathrm{Pb} 83 \mu \mathrm{g} / \mathrm{kg}$ (fresh weight), $\mathrm{Cd} 13 \mu \mathrm{g} / \mathrm{kg}$ 
Table 2. Body-weights of rats receiving glucose or xylitol for 8 weeks

(Mean values and standard deviations for nine animals per group)

\begin{tabular}{|c|c|c|c|c|c|c|c|c|}
\hline \multirow{3}{*}{$\begin{array}{l}\text { Dietary group } \\
\text { Period of } \\
\text { experiment (d) }\end{array}$} & \multicolumn{8}{|c|}{ Body-weights (g) } \\
\hline & \multicolumn{2}{|c|}{ Control } & \multicolumn{2}{|c|}{$\begin{array}{c}200 \mathrm{~g} \\
\text { Glucose } / \mathrm{kg}\end{array}$} & \multicolumn{2}{|c|}{$\begin{array}{c}50 \mathrm{~g} \\
\text { Xylitol/kg }\end{array}$} & \multicolumn{2}{|c|}{$\begin{array}{c}200 \mathrm{~g} \\
\text { Xylitol/kg }\end{array}$} \\
\hline & Mean & SD & Mean & SD & Mean & SD & Mean & sD \\
\hline Start & 331 & 20 & 325 & 15 & 334 & 17 & 331 & 11 \\
\hline 28 & 371 & 22 & 381 & 13 & 378 & 14 & $348^{*}$ & 20 \\
\hline 56 & 399 & 21 & $424^{*}$ & 21 & 400 & 13 & $362^{* *}$ & 20 \\
\hline
\end{tabular}

Values were significantly different from those for the control group: $* P<0.05, * * P<0 \cdot 01$.

Table 3. Iron concentrations in tissues of rats receiving glucose or xylitol for 8 weeks (Mean values and standard deviations for nine animals per group)

\begin{tabular}{|c|c|c|c|c|c|c|c|c|}
\hline \multirow{3}{*}{$\begin{array}{l}\text { Dietary group } \\
\text { Tissue }\end{array}$} & \multicolumn{8}{|c|}{$\mathrm{Fe}$ concentration (mmol/ $\mathrm{kg}$ fresh tissue) } \\
\hline & \multicolumn{2}{|c|}{ Control } & \multicolumn{2}{|c|}{$\begin{array}{c}200 \mathrm{~g} \\
\text { Glucose } / \mathrm{kg}\end{array}$} & \multicolumn{2}{|c|}{$\begin{array}{c}50 \mathrm{~g} \\
\text { Xylitol/kg }\end{array}$} & \multicolumn{2}{|c|}{$\begin{array}{c}200 \mathrm{~g} \\
\text { Xylitol } / \mathrm{kg}\end{array}$} \\
\hline & Mean & SD & Mean & SD & Mean & SD & Mean & SD \\
\hline Serum $(\mu \mathrm{mol} / \mathrm{l})$ & 37.8 & $2 \cdot 6$ & $32 \cdot 3^{* * *}$ & 2.9 & 38.6 & $4 \cdot 8$ & $41.9 *$ & $5 \cdot 1$ \\
\hline Liver & $1 \cdot 58$ & 0.23 & 1.72 & $0 \cdot 17$ & 1.72 & $0 \cdot 14$ & $2 \cdot 00^{* *}$ & 0.29 \\
\hline Kidney & 1.54 & $0: 18$ & 1.49 & $0 \cdot 20$ & $1 \cdot 31^{*}$ & $0 \cdot 19$ & 1.47 & $0 \cdot 16$ \\
\hline Duodenum wall & 0.65 & $0 \cdot 17$ & 0.65 & 0.19 & 0.69 & $0 \cdot 15$ & $0.80^{*}$ & 0.12 \\
\hline Spleen & 9.98 & $2 \cdot 51$ & $12 \cdot 50^{*}$ & $2 \cdot 20$ & $13 \cdot 06^{*}$ & $2 \cdot 54$ & $14 \cdot 45^{*}$ & $4 \cdot 14$ \\
\hline Bone marrow $\dagger$ & $9 \cdot 54$ & 1.32 & $9 \cdot 75$ & 1.38 & 9.55 & 0.88 & $12.02^{* *}$ & 1.59 \\
\hline
\end{tabular}

Values were significantly different from those for the control group: ${ }^{*} P<0.05,{ }^{* *} P<0.01,{ }^{* * *} P<0.001$.

$\dagger$ Dry weight basis.

(fresh weight). Most of the values measured were similar to those given by the reagent blanks. The experimental groups did not differ.

\section{DISCUSSION}

The food of the animals supplied ferrous-Fe at a relatively high level. Therefore, the Fe stores of the rats were saturated and the storage of new Fe progressed at a low rate. However, dietary factors like xylitol seemed to alter the rate of $\mathrm{Fe}$ absorption and storage in several rat tissues. Obviously, rats were able to utilize dietary Fe in excess of their actual physiological needs. Under certain conditions, xylitol may thus function as an agent favouring Fe absorption, in line with certain other ligands which form relatively weak complexes with Fe (Turnbull, 1974).

The mechanism of increased Fe absorption may be attributed to several phases of $\mathrm{Fe}$ metabolism, four of which are discussed below: (1) complex formation between polyvalent metal cations and polyhydroxy systems occur under physiological conditions (Angyal et al. 1974; Kieboom et al. 1975). These complexes may be taken up by the mucosal cells more easily than ionized Fe alone (Turnbull, 1974); (2) xylitol, as an Fe-complexing agent, may prevent the metabolic oxidation of ferrous-Fe into the less-soluble ferric form. This situation would resemble ingestion of ascorbic acid together with Fe for keeping the latter 
in soluble ferrous state and promoting its absorption (Lynch \& Cook, 1980). The formation of reduced $\mathrm{Fe}$ is further favoured by the reducing conditions that may be produced in the intestinal lumen after peroral administration of xylitol; (3) after mucosal uptake, xylitol-Fe complexes may be less susceptible to form mucosal Fe stores (mainly with ferritin) but pass instead through the cell into the portal blood. The mucosal Fe stores were suggested to constitute the system regulating Fe absorption (Conrad \& Crosby, 1963); (4) in blood, serum $\mathrm{Fe}$ is bound to transferrin whose affinity for $\mathrm{Fe}$ is much greater than that of most chelating agents (Morgan, 1974). Fe release from transferrin to the storing ferritin molecules seems to be affected by several chelating agents in plasma (Morgan, 1974). Such agents may include polyols like sorbitol and xylitol.

\section{REFERENCES}

Angyal, S. J. \& Davies, K. P. (1971). Chemical Communications, 500-501.

Angyal, S. J., Greeves, D. \& Mills, J. A. (1974). Australian Journal of Chemistry 27, 1447-1456.

Angyal, S. J. \& Mills, J. A. (1979). Australian Journal of Chemistry 32, 1993-2001.

Bothwell, T. H. \& Finch, C. A. (1962). Iron metabolism, p. 26. London: J. \& A. Churchill Ltd.

Conrad, M. E. Jr \& Crosby, W. H. (1963). Blood 22, 406-415.

Feldkamp, C. S., Watkins, R., Baginski, E. S. \& Zak, B. (1977), Microchemical Journal 22, 335-346.

Hämäläinen, M. M. \& Mäkinen, K. K. (1981). Journal of Nutrition 111, 107-122.

Herndon, J. F., Rice, E. G., Tucker, R. G., Van Loon, E. J. \& Greenberg, S. M. (1958). Journal of Nutrition 64, 615-623.

Kieboom, A. P. G., Spoormaker, T., Sinnema, A., van der Toorn, J. M. \& van Bekkum, H. (1975). Recueil des Travaux Chimiques du Pays-Bas 94, 53-59.

Lynch, S. R. \& Cook, J. D. (1980). Annals of the New York Academy of Sciences 355, 32-44.

Mäkinen, K. K. (1978). Experientia Suppl. 15, 1-160.

Morgan, E. H. (1974). In Iron in Biochemistry and Medicine, pp. 29-71 [A. Jacobs \& M. Worwood, editors]. London: Academic Press.

Turnbull, A. (1974). In Iron in Biochemistry and Medicine, pp. 369-403 [A. Jacobs \& M. Worwood, editors]. London: Academic Press. 